\title{
UDZIAŁ PLOTKI I PLOTKOWANIA W KOMUNIKACJI USTNEJ NA PRZYKLADZIE KOMUNIKACJI BIUROWEJ - PODEJŚCIE HYBRYDOWE: PRAGMA- SOCJO-, PSYCHO- ORAZ EKOLINGWISTYCZNE
}

\author{
JERZY KAUS, STANISŁAW PUPPEL
}

\begin{abstract}
The article aims at analysing the concept of gossip at workplace. The main goal of the article is to answer such questions as: what is gossip? Who is involved in spreading gossip at workplace? What are the sources of gossips? The first part (section 1) of the article is theoretical and aims at defining the concept of gossip. The second part (sections 2 and 3) analyses the results of a questionnaire which was carried out among forty respondents. The results are compared with the theoretical assumptions put forth by a number of research works discussed briefly in the article.
\end{abstract}

Key words: gossip, the process of gossiping, fake news, sources of gossip, verbal and nonverbal parameters of gossip

\section{Wstęp}

Plotka jest częścią interakcji międzyludzkich o charakterze werbalnym. Posługujemy się plotką $\mathrm{w}$ różnych układach interakcyjno-komunikacyjnych, np. $\mathrm{w}$ formalnym układzie miejsca pracy, w życiu prywatnym, w mediach, np. telewizji, $\mathrm{w}$ prasie, w Internecie. Ten gatunek interakcji werbalnej odgrywa ważną rolę w naszym życiu. Ponieważ plotka jest ważnym elementem komunikacji werbalnej, stanowi od lat temat badań i rozważań, w których jest ona opisana przez badaczy 
wykorzystujących różne metodologie i perspektywy badawcze. Warto tu wymienić cztery zasadnicze podejścia językoznawcze, a mianowicie socjolingwistyczne, pragmalingwistyczne, psycholigwistyczne (a więc oparte na psychologii, zob. np. Reykowski, 1974; Thiele-Dohrmann 1975/1980; Boksa, Kołodziejczak, 2019; Jęczeń, 2011) i najnowsze, ekolingwistyczne. Dostępne opracowania koncentrują się na ogólnej charakterystyce zjawiska plotki i procesu plotkowania (zwanego dalej 'plotkowaniem'). Dlatego też warto przyjrzeć się bliżej właśnie procesowi plotkowania. Ten artykuł jest próbą opisania procesu plotkowania w określonym układzie interakcyjno-werbalnym, w miejscu pracy.

Przyjęto w nim następujące hipotezy badawcze: 1) zjawisko plotki jest ważnym elementem życia zawodowego. 2) plotkowanie jest nie tylko formą komunikacji werbalnej w miejscu pracy lecz pełni istotną funkcję integracyjną dla danej grupy komunikatorów należących do formalnego układu miejsca pracy. Celem niniejszego artykułu jest znalezienie odpowiedzi na następujące pytania szczegółowe: czym jest plotka, dlaczego plotkujemy w miejscu pracy, z kim plotkujemy najczęściej, jak często plotkujemy, kto najczęściej plotkuje w miejscu pracy: młodsi czy starsi stażem pracownicy oraz jakie są efekty plotkowania. W artykule omówiono również różnice $\mathrm{w}$ sposobie plotkowania $\mathrm{w}$ zależności od tego, czy mamy do czynienia z komunikacją bezpośrednią 'twarzą-w-twarz' czy pośrednią, która stała się szczególnie popularna $\mathrm{w}$ okresie izolacji społecznej spowodowanej pandemią koronawirusa i przejścia do pracy w trybie on-line. Jak już zaznaczono w tytule pracy, zjawisko plotki i proces plotkowania zostaną przedstawione z mieszanej perspektywy socjolingwistycznej, pragmalingwistycznej, psycholingwistycznej oraz ekolingwistycznej. Przyjęte hipotezy badawcze zostaną zweryfikowane za pomocą ankiety. W pierwszej części artykułu (podrozdział 1) omówione zostaną teoretyczne zagadnienia związane $\mathrm{z}$ procesem plotkowania. W drugiej części (podrozdziały 2 i 3 ) pokazane zostaną wyniki przeprowadzonej ankiety.

\section{Czym jest plotka?}

Zdaniem badaczy zajmujących się plotką w szerszej perspektywie kulturowojęzykoznawczo-komunikacyjnej plotka i plotkowanie są ważnymi i złożonymi składnikami interakcji międzyludzkich o charakterze werbalnym (aspekt społeczny języka w kontekście plotki i plotkowania). Jego złożoność oraz umiejscowienie w kontekście naturalnym podkreśla Dariusz Gronowski (2016: 63). Z kolei Robin Dunbar (1996/2009: 101) podkreśla, że plotka jako taka ma swoje znaczące miejsce w ewolucji języka i kultury (zwłaszcza w kontekście uczenia się społecznego, ang. cultural learning, np. rozwój zasobów językowych poprzez plotkę miał pomagać męskim członkom plemienia w koordynacji polowań, także w wewnątrz-plemiennej wymianie opowiadań (tworzeniu mitologii) o świecie duchowym lub pochodzeniu 
danego plemienia). Wartość plotki dla ewolucji języka jako systemu komunikacyjnego ma więc niezwykle istotne znaczenie, szczególnie w kontekście rozwoju zachowań prospołecznych u człowieka i kohezji wewnątrzgrupowej (zob. np. Feinberg i inni, 2012).

Wymieniony powyżej Gronowski (2016: 62) podkreśla, że człowiek ma potrzebę nawiązania kontaktu werbalnego z innymi osobami a przede wszystkim bycia przez nie wysłuchanym. Plotka zatem jest umiejscowiona w doświadczeniu językowym człowieka, które według Dunbara (1996/2009: 14) „pozostaje naszym największym skarbem. Bowiem (...) ,język umożliwia nam bycie członkami społeczności oraz wymianę wiedzy i doświadczeń na skalę nieosiągalną dla żadnego innego gatunku”. Zdaniem Dunbara (1996/2009: 11), „około dwóch trzecich wszystkich rozmów obraca się wokół spraw natury towarzysko-socjalnej”. Taki właśnie udział plotki w ogólnej strukturze wymiany werbalnej określony został przez drugiego autora niniejszej pracy mianem udziału w 'niszy rutyny codziennej i kultury ogólnej' (ang. daily routine and general culture niche, zob. Puppel, 2017). Nisza ta dominuje w praktyce komunikacyjnej człowieka o charakterze werbalnym zarówno w zakresie jej procentowego udziału jak i typu zasobów językowo-komunikacyjnych biorących w niej udział.

Warto $\mathrm{w}$ tym miejscu postawić pytanie o charakterze pragmalingwistycznym: Czym jest samo plotkowanie? Przyjmujemy za oczywistość, że plotkowanie polega na wzajemnym przekazywaniu informacji za pomocą głównie zasobów potocznych języka. Tymczasem w podejściu pragmalingwistycznym możemy mówić o plotce i plotkowaniu jako działalności komunikacyjnej z zawartą w niej intencjonalnością, np. świadomym wprowadzaniem elementów nieprawdy do komunikatów określanych jako plotka. Podkreśla ten właśnie element Agnieszka Jęczeń (2011: 110), która zauważyła, że „plotka to niesprawdzona lub kłamliwa wiadomość powtarzana z ust do ust, najczęściej szkodząca czyjejś opinii”.

Proces plotkowania (odnosi się to zresztą do procesu generowania wszelkich komunikatów językowych we wszystkich trzech niszach komunikacyjnych: niszy kultury codziennej i kultury ogólnej, niszy zawodowej i niszy obywatelskiej) można przedstawić za pomocą znanego modelu komunikacji Romana Jakobsona, który składa się z nadawcy, odbiorcy, kontekstu, komunikatu, kontaktu i kodu. Model komunikacji Jakobsona przedstawiono na rysunku 1.

W plotkowaniu w określonym układzie interakcyjnym (np. miejscu pracy, ang. workplace) nadawca przekazuje komunikat (np. zasłyszane przez niego informacje) odbiorcy w interakcji międzyosobowej (w szczególności w kontakcie bezpośrednim) za pomocą określonego kodu językowego (komunikacji werbalnej wspomaganej w interakcji bezpośredniej przez elementy komunikacji niewerbalnej). Każda przekazywana plotka dotyczy określonego kontekstu w postaci miejsca i treści komunikatu. Dodatkowo parametry składające się na plotkę można przedstawić w następujący sposób (Wagner, 2006: 45): 


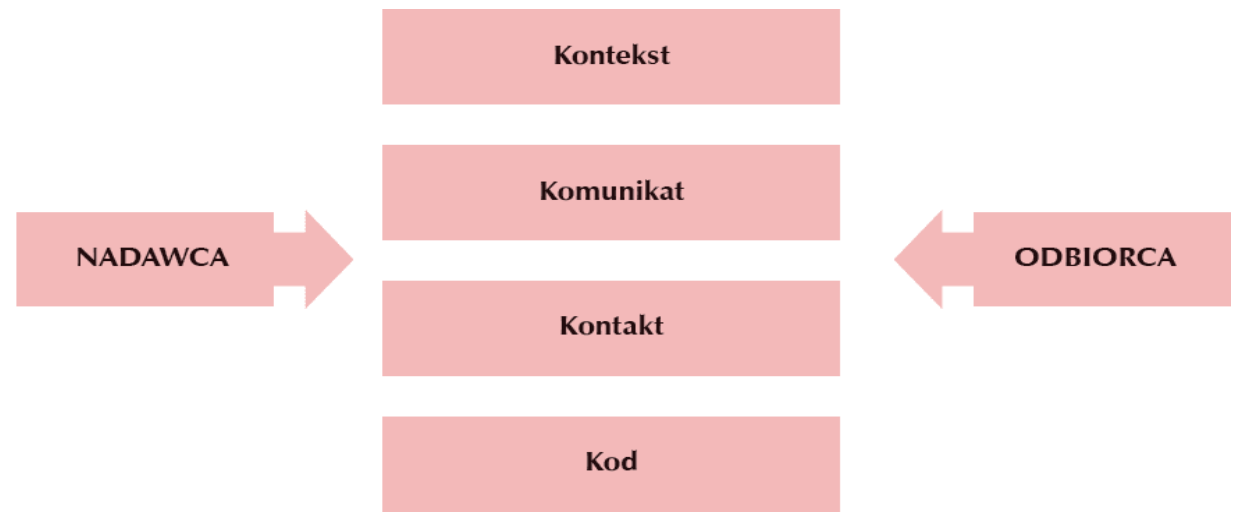

Rys. 1. Model komunikacji według Jakobsona (ŹI 5)

- „wariantywność oznaczająca w praktyce różne wersje przekazów (...)

- zaangażowanie dotyczy faktu, że przekazujący plotkę postrzega jej treść jako ważną (...)

- negatywna treść - jest to dominująca cecha plotki. Badacze szacują, że około 90 procent plotek to plotki czarne donoszące o agresji, wypadkach, oszustwach, skandalach (...)

- przypisywanie plotki wiarygodnemu źródłu - chodzi o podanie domniemanego źródła (...)".

Z kolei Tracy Wilson (ŹI 6) twierdzi, że plotkę można opisać biorąc pod uwagę takie kryteria jak to, że:

- „rozmowa odbywa się na osobności

- rozmawiający przekazują informacje tak jakby były one faktami

- osoby plotkujące porównują się do osoby, o której plotkuje się (...)" (thumaczenie własne, JK).

Warto w tym miejscu zadać kolejne dwa pytania o charakterze językoznawczym, a ściślej sygnalizującym najnowsze podejście ekolingwistyczne, a mianowicie: za pomocą jakich zasobów językowo-komunikacyjnych przekazujemy plotkę? oraz: za pomocą jakiego ‘syndromu komunikacyjnego' można opisać osoby przekazujące zasłyszane informacje? Odpowiedź na te ważne pytania zostanie udzielona w dalszej części artykułu.

Tymczasem z perspektywy psychologicznej można przyjąć, że plotkujemy na tematy innych ludzi i zdarzeń, zwłaszcza innych osób, tworząc tzw. projekcje, które można zdefiniować jako tworzenie „wyobrażenia” o osobie lub przedmiocie (zob. Thiele-Dohrmann, 1975/1980: 99). Musimy także pamiętać, że plotkowanie podzielić można na pozytywne i negatywne (zob. Bronagh i McKeown, 2020). Do pozytywnych zachowań można zaliczyć wyraz twarzy (ang. facial expression, np. uniesione oczy, opadnięta szczęka) oraz zachowania akustyczno-audialne, np. śmiech. 
Natomiast do zachowań negatywnych można zaliczyć wyraz twarzy wskazujący na obojętność lub pogardę ze strony autora plotki (zob. Bronagh i, McKeown, 2020) lub płacz.

Kolejne pytanie, które możemy zadać, brzmi: jaka jest różnica pomiędzy plotką a tzw. fałszywą wiadomością celowo wprowadzaną do komunikatów w interakcji werbalnej międzyludzkiej (ang. fake news)? Przyjmujemy za Gronowskim (2016: 2), że plotka dotyczy wiadomości zasłyszanej, która jest przekazywana rozmówcy w interakcji międzyludzkiej. W uzupełnieniu możemy dodać, że jak zauważa Magdalena Mateja (2010: 275), plotki można podzielić na „czarne donoszące o agresji, wypadkach, skandalach, oszustwach, itp. Tylko $10 \%$ stanowią plotki różowe zawierające doniesienia o wydźwięku pozytywnym". Zatem można wyróżnić dwa rodzaje plotek: plotki o kimś (osoby) oraz o czymś (zdarzenia, zjawiska, etc.). Możemy też skorzystać z typologii pragmalingwistycznej zaproponowanej przez dwie badaczki, Ewę Boksę i Justynę Kołodziejczyk (2019: 298), które proponują następujący podział plotki: 1) plotka „supozycyjna” - bazująca na „domysłach”, 2) plotka „niespodzianka" - streszczenie widzianego przez autora plotki wydarzenia słuchaczowi, 3) plotka „gadzinówka” - bohater plotki jest poddany krzywdzącym opiniom”. Jak można zatem zauważyć, z punktu widzenia pragmalingwistyki, plotka jest wiadomością przekazywaną ustnie, a więc głównie wykorzystującą ustny porządek komunikacyjny, z wyraźnym elementem intencjonalności.

Podsumowując ten fragment niniejszego opracowania, stwierdzamy, że plotka to w klasycznej postaci przekaz ustny, który dotyczy zazwyczaj zasłyszanych niesprawdzonych tematów (np. dotyczy osób nieobecnych w momencie przekazywania wiadomości lub informacji o niesprawdzonych 'faktach'). Z kolei z badań Tracy Wilson (ŹI4), wynika, że plotce i plotkowaniu przyznać należy następujące bardziej socjolingwistyczne parametry, a mianowicie: spotkanie z rozmówcą na osobności (a więc bez obecności osoby będącej przedmiotem plotki), przekazanie zasłyszanych plotek swojemu rozmówcy, dokonanie intuicyjnej oceny zasłyszanych informacji. Należy zadać w tym miejscu pytanie odnośnie wyłączności użycia ustnego porządku komunikacyjnego: czy plotka jest przekazywana tylko ustnie, a więc tylko w audio(ustno)-wokalnym porządku komunikacyjnym? Jak podaje Stanisław Puppel (2015: 144), komunikację werbalną można przeprowadzić w następujących „,porządkach: ustno-wokalny (...) oparty na wokalności ustno-wokalnej, (...) wtórny (rozszerzony) porządek komunikacyjny graficzno-pisany oparty na modalności dotykowo-wzrokowej oraz (...) porządek hybrydowy (mieszany) foniczno-graficznowizualny (...) (np. obrazy ruchome - animacje filmowe)". Dzięki zaistnieniu nowych technologii informacyjnych, plotkować możemy jednocześnie we wszystkich wyżej przedstawionych porządkach komunikacyjnych.

Procesy plotkowania $\mathrm{w}$ formalnym układzie miejsca pracy zostaną poddane analizie w części eksperymentalnej artykułu. Tematy, definicje i działania związane z plotkowaniem opisała w swojej monografii Ewa Błachowicz-Wolny (1995). Au- 
torka podkreśla semantyczno-dystrybucyjny charakter plotki i plotkowania, stwierdzając, że „plotka najczęściej dotyczy spraw osobistych (1995: 174), „może być bzdurna, kłamliwa" (1995: 36). Co więcej, autorka ta (1995: 36) twierdzi, że plotka ma charakter wybitnie rekursyjny, gdyż „plotkę można opowiadać, powtarzać, roznosić, rozpuszczać (...) [opowiadać nieprawdziwe] historie". Stanowi ona zatem istotny element dyskursu werbalnego i tym samym ma charakter społeczny, nie tylko w wymiarze bezpośredniej komunikacji międzyosobowej, ale także w wymiarze grupowym poprzez swój charakter wybitnie wzajemnościowy (zob. np. Berg i inni, 1995).

Można się w tym miejscu pokusić o zadanie następującego pytania: Kto więcej stosuje plotkę w komunikacji werbalnej międzyosobowej, kobiety czy mężczyźni? $\mathrm{W}$ ostatnich latach pojawia się coraz więcej badań, które wskazują na fakt, że zarówno mężczyźni jak i kobiety bardzo lubią plotkować (zobacz na przykład: Watson, 2012; Eckhaus i Ben-Hador, 2017; Pawłowska ŹI3; Boksa i Kołodziejczak, 2019), chociaż jednocześnie badacze wskazują na zauważalne różnice w uprawianiu plotki oparte na płci społeczno-kulturowej (ang. gender differences, zob. Leaper i Friedman, 2007). Podobne wyniki otrzymali Jack Levin i Arnold Arluke (1985), którzy w swoich wczesnych badaniach nad plotką stwierdzili, że zarówno kobiety jak i mężczyźni plotkują na wiele podobnych tematów. Jednocześnie stwierdzono $\mathrm{w}$ innych badaniach, że kobiety bardziej zachęcają do stosowania plotki w ramach swojej płci w celu ustanowienia silniejszej więzi między sobą jak i czynienia porównań z innymi osobami (zob. Leaper i Holliday, 1995). Przyjmuje się więc, że plotkarz/plotkarka to osoba, która, najogólniej rzecz ujmując, chce nawiązać kontakt $\mathrm{z}$ innymi osobami $\mathrm{w}$ celu utrzymania więzi interpersonalnej oraz podtrzymania wymiany komunikatów werbalnych o charakterze plotki, a więc komunikatów o treści ewaluacyjnej o kimś/czymś zewnętrznym wobec nadawcy komunikatu, obejmujących różnorodność tematyczną (zob. np. Foster, 2004). Oczywiście musimy także pamiętać, że plotka może stanowić sposób na nasze osobiste istnienie w grupie, bowiem, jak wskazały wczesne badania Sidneya Jourarda (1959), kwantum informacji, które jesteśmy gotowi przekazać innym o sobie jest ściśle skorelowane ze stopniem zażyłości z innymi osobami, więc: im mniej się znamy, tym mniej o sobie przekazujemy innym.

Ewaluacyjność plotki ma z pewnością charakter psychologiczny. Za przykład psychologicznego sprofilowania osób używających plotki, można podać, że na podstawie dostępnych badań osobami, które skłonne są w większym stopniu do używania plotki i plotkowania są osoby określane jako 'ekstrawertycy' (zob. podstawowa typologia Junga z 1921 roku). Postawa ekstrawertyków w generowaniu plotek wynika $\mathrm{z}$ większej chęci nawiązania przez takie osoby kontaktu z innymi osobami. Z kolei według Klausa Thiele-Dohrmanna (1975/1980: 52), „ludzie odznaczający się gotowością do plotkowania [przenoszą] własne skrywane przed sobą wady na osobę oplotkowaną [budują] historie nie mające nic wspólnego z faktami”. 
Dlaczego zatem stosujemy plotkę i wchodzimy w złożone procesy plotkowania? Beata Kurządkowska i Marek Maruszczak (2014: 140) podają dalsze istotne czynniki psychologiczne i podkreślają, że źródłem plotek jest „,strach (niepewność), ciekawość i chęć zemsty". Z kolei, według Klausa Thiele-Dohrmanna (1975/1980: 18), „bardzo ważnym motywem plotki jest strach (...) przeważnie nieświadomy, skrywany przed samym sobą lęk (...) przed opinią innych, przed ewentualną negatywną oceną własnej osoby przez spotkanego człowieka czy przez anonimową zbiorowość”. Jak podają dalej Kurządkowska i Maruszczak (2014: 140), „zanim ktoś nas zaatakuje, najlepszym rozwiązaniem jest uprzedzenie jego ruchu. Jednak w obawie przed bezpośrednią konfrontacją najlepszą możliwością staje się atak na osobę nieobecną.” Thiele-Dohrmann (1975/1980: 21) argumentuje ponadto, że „,[d]o najważniejszych motywów plotki należy ciekawość. To, co nieznane, pobudza wyobraźnie, zwłaszcza, gdy chodzi o sprawy uchodzące za ważne. Własną ciekawość człowiek stara się zaspokoić przy pomocy fantazjowania; plotkując wypełnia luki niewiedzy. (...)”. Według Kurządkowskiej i Maruszczaka (2014: 140), „[p]lotka jako wynik zemsty, jest najbardziej spontaniczna, najbardziej przemyślana, a jednak często bywa używana z premedytacją. Powstaje pod wpływem emocji (...)”. Ważnym parametrem plotki ,jest przyjemność obrażania innych" (Thiele-Dohrmann 1975/1980: 24). W tym miejscu możemy stwierdzić, że plotka zawiera w sobie ważne elementy psychologiczno-kognitywne (możemy to określić jako indywidualne rozpoznanie plotką), co z pewnością wiąże się z psycholingwistycznymi aspektami w uprawiania plotki, a więc powiązaniem użycia językowego $\mathrm{z}$ indywidualnymi cechami osoby uprawiającej plotkę.

Proces plotkowania można również przedstawić z perspektywy ekolingwistycznej. Według Stanisława Puppla (2013), wszelkie zachowanie człowieka w komunikacji (werbalnej i niewerbalnej) można zobrazować za pomocą Wielkiego Układu Życia, który można przedstawić w następujący sposób:

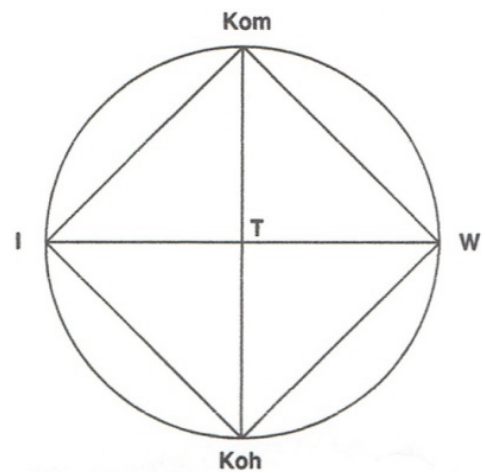

Rys. 2. Wielki Układ Życia (źródło, Puppel, 2016; Krawczak, 2017: 15) 
Zaproponowane przez Puppla parametry Wielkiego Układu Wcielenia to: Kohabitacja (Koh), Interakcyjność (I) Komunikacja (Kom), Tożsamość (I), Wcielenie (W) (zob. Puppel, 2016 w Krawczak, 2017: 158). Puppel pisze, że (2016: 48), na powstanie tożsamości, którą posiadają wszelkie byty ( $\mathrm{T}$, w tym człowiek jako komunikator), wpływ mają cztery parametry:

- cielesność (ang. embodiment) - wyrazić ją można za pomocą następującego określenia: 'oto jestem';

- kohabitacja (ang. cohabitation) - wyrazić ją można za pomocą następującego określenia: 'nie jestem sam/a na nośniku ziemskim i w uniwersalnej przestrzeni biologicznej';

- interakcyjność (ang. interactivity) - wyrazić ją można za pomocą następującego określenia: 'z konieczności wpadam na innych, skazany/a jestem na obecność innych cielesności w uniwersalnej przestrzeni biologicznej, zwłaszcza w obrębie mojego gatunku';

- komunikacja (ang. communication) - wyrazić ją można za pomocą następującego określenia: 'posiadam określone zasoby i dzielę się nimi z innymi przedstawicielami mojego gatunku'.

Według Puppla (2017), w interakcji międzyludzkiej pomiędzy nadawcą a odbiorcą zachodzi synergia (tj. wzajemne oddziaływanie, Puppel, 2017). W tym szerokim kontekście, plotka jako element wymiany informacji o charakterze werbalnym może wywołać u odbiorcy określoną reakcję interakcyjno-emocjonalną (np. wzburzenie) lub jej brak (np. zignorowanie plotki) (mówi o tym także Reykowski, 1974). Ponadto, jak stwierdza Grzegorz Szczerba (2013: 81), ,za pomocą plotek sprawny manipulator może stopniować napięcie [emocjonalne] lub wzmagać zainteresowanie słuchaczy". Należy dodać, że napięcie emocjonalne stanowi niezwykle ważny element interakcyjności międzyosobowej w uprawianiu plotki jako formy komunikacji werbalnej. Warto także podkreślić, że w komunikacji międzyosobowej poszczególni komunikatorzy mają do swojej dyspozycji trzy tzw. 'syndromy komunikacyjne' (zob. Puppel, 2004: 21; Puppel, 2017), które można podzielić na:

1) Syndrom Petroniusza - osoby, które można opisać za pomocą tego syndromu, posiadają ,wysokie zasoby językowe oraz zawsze używają najbardziej wyrafinowanych zasobów językowych niezależnie od ich aktualnej oceny zmieniającego się kontekstu spotkań komunikacyjnych (...)" (ibid, 2004: 21).

2) Syndrom Guliwera - osoby, które cechują się tym syndromem, mają wysokie zasoby językowe, jednak w interakcji międzyosobowej zmieniają odpowiednio jakość swoich zasobów językowych „w zależności od ich aktualnej oceny, zmieniającego się kontekstu spotkań komunikacyjnych i ich zmieniającego się zaangażowania komunikacyjnego" (ibid, 2004: 21).

3) Syndrom Oskara - osoby, które można opisać za pomocą tego syndromu, posiadają „niskie (...) zasoby językowe i stąd nieustannie stosują mocno ograniczone (słabo rozwinięte) zasoby językowe niezależnie od zaangażowania komunikacyjnego (...)" (Puppel, 2004: 11). 
Syndromy te, z pewnością zaś niezwykle elastyczny Syndrom Guliwera, uczestniczą w stosowaniu plotki i plotkowaniu w wykonaniu danego komunikatora, przyczyniając się nie tylko do generowania zjawiska powiązań międzyosobowych (o charakterze pragmatycznym i społeczno-psychologicznym), ale także do zjawiska różnorodności $\mathrm{w}$ plotkowaniu ze względu zarówno na zasoby językowo-komunikacyjne jak i ze względu na indywidualne style uprawiania plotki przez poszczególne osoby (zob. np. Nettle, 2007).

Założywszy, że komunikacja ludzka następuje zawsze w określonych niszach komunikacyjnych, zachodzi pytanie: $w$ jakich niszach komunikacyjnych plotkujemy? Zdaniem Puppla (2004), każdego dnia komunikujemy się w trzech różnych, często nachodzących na siebie, niszach komunikacyjnych, takich jak, 'nisza rutyny codziennej i kultury ogólnej', 'nisza zawodowa" (ang. professional niche), czy wreszcie 'nisza obywatelska' (ang. citizenship niche, - zaliczyć można do tej ostatniej np. konstytucje, prawa, konwencje, zarządzenia, umowy - wszystkie pisane dokumenty o charakterze prawnym).

Przyjmujemy, że plotkowanie występuje w sposób najbardziej naturalny (nienacechowany) w niszy rutyny codziennej i kultury ogólnej (np. spotkaniach rodzinnych, towarzyskich oraz nieplanowanych spotkaniach w różnych typach przestrzeni komunikacyjnej, zwłaszcza na tzw. 'agorze', a więc najbardziej ogólnej przestrzeni komunikacyjnej człowieka, zob. Puppel, 2017: 75; Wiertlewska, 2014: 106). Każdy ludzki komunikator ma dostęp do tego rodzaju niszy (w zasadzie ze względu na swoje nienacechowanie najłatwiejszej, zob. Puppel, 2017: 75). Jak dalej wyjaśnia Janina Wiertlewska (2014: 106), „nisza zachowań codziennych i kultury codziennej jest najbardziej dominująca spośród (...) trzech nisz, obejmując swym zasięgiem największą część języka jako, że penetruje ona komunikację codzienną w rodzinach, w domach, czy wśród znajomych". Tematy poruszane w tej niszy dotyczą spraw codziennych oraz wykorzystuje się w niej najbardziej powszechne i dalekie od profesjonalności zasoby językowe. W tej niszy używane jest słownictwo powszechne (tzw. codzienne), które dotyczy najbardziej podstawowych typów interakcji werbalnych, a więc: relacji z najbliższymi, religii, transportu, bieżących wydarzeń kulturalnych, obrony, jedzenia, zdrowia, pogody, wszelkich nieplanowanych (przypadkowych) spotkań (Puppel, 2017: 75).

Należy w tym miejscu podkreślić, że powszechna „dostępność niszy rutyny codziennej oraz kultury ogólnej dla użytkowników stanowi ważny parasol ochronny dla danego języka naturalnego, bowiem ze względu na swój powszechny charakter chroni każdy język naturalny przed nadmierną inwazją innych języków naturalnych oraz, co warte szczególnego podkreślenia, wspomaga odporność każdego języka naturalnego (Puppel, 2017: 75, thumaczenie własne, JK). Jest więc rzeczą oczywistą, że z punktu widzenia ekolingwistyki, uprawianie plotki w niszy rutyny codziennej i kultury ogólnej ma niewątpliwie istotne znaczenie dla utrzymania (i nawet konserwacji) danego języka naturalnego w średnio-niskim rejestrze zasobów językowo-komunikacyjnych. 
W tej części artykułu przedstawione zostały mieszane kryteria socjolingwistyczne, psychologiczno-psycholingwistyczne, pragmalingwistyczne oraz ekolingwistyczne w odniesieniu do zjawiska plotki i plotkowania. W części eksperymentalnej przedstawione zostaną i omówione odpowiedzi na pytania zawarte $\mathrm{w}$ kwestionariuszach. Pomogą one $\mathrm{w}$ zrozumieniu zjawiska plotki i plotkowania $\mathrm{w}$ formalnym układzie miejsca pracy.

\section{Badanie pilotażowe}

Po charakterystyce plotki oraz procesu plotkowania w oparciu o badania omówione zostanie zagadnienie plotki w miejscu pracy. Ankietowanymi zostały zadane następujące pytania

1) Czy lubimy plotkować w miejscu pracy?

2) Z kim najczęściej plotkujemy w miejscu pracy?

3) Na jakie tematy plotkujemy?

4) O jakiej porze dnia najczęściej plotkujemy?

5) W jakim miejscu najczęściej plotkujemy?

6) Jak często plotkujemy?

7) Dlaczego plotkujemy w miejscu pracy?

8) Kto najczęściej plotkuje w miejscu pracy: młodsi stażem pracownicy czy starsi stażem pracownicy?

9) Czy wierzysz w plotki poruszane w Twoim miejscu pracy?

10) Jakiego języka używają osoby, które plotkują w Twoim miejscu pracy?

11) Jakie zasoby językowe wykorzystywane są podczas plotkowania?

12) Czy podczas plotkowania dochodzi do skrócenia dystansu międzyosobowego?

13) Jaki jest odstęp pomiędzy plotkującymi w miejscu pracy?

Odpowiedzi na powyższe pytania i ich analiza zostaną przedstawione w części dotyczącej wyników badania ankietowego.

W celu uzyskania odpowiedzi na powyższe pytania przeprowadzone zostały dwie ankiety pilotażowe na serwisie społecznościowym facebook. W pierwszej ankiecie uczestniczyło 50 osób. W ankiecie uczestniczyły zarówno kobiety jak i mężczyźni. Celem wybranej przez drugiego autora niniejszego opracowania metody badawczej było pozyskanie jak największej liczby zróżnicowanych danych, która można poddać analizie. Wybrana metoda badawcza miała na celu zebranie opinii respondentów na temat plotki przekazywanej ustnie w komunikacji międzyosobowej $\mathrm{w}$ formalnym układzie miejsca pracy. Celem drugiej ankiety było zebranie opinii na temat plotkowania w Internecie oraz uzyskanie odpowiedzi na pytanie jak ewoluuje plotka w komunikacji międzyosobowej. Pierwsza ankieta składa się z 13 pytań. 
Na pytanie 1: czy lubimy plotkować w miejscu pracy? 35\% badanych odpowiedziało: Nie, $65 \%$ badanych odpowiedziało: Tak. Zebrane wyniki można przedstawić za pomocą następującego wykresu:

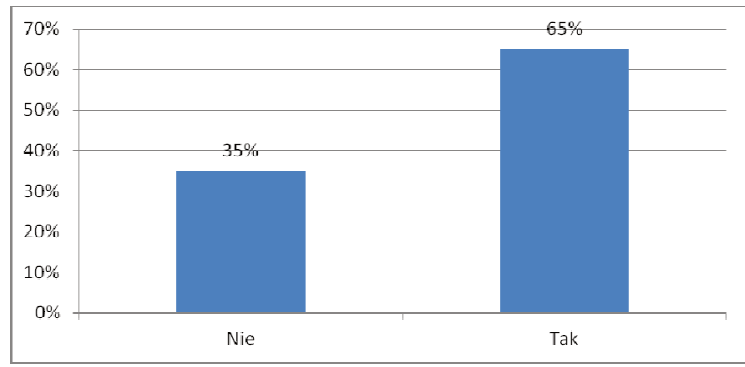

Wykres 1 . Czy lubimy plotkować w miejscu pracy?

Na pytanie 2: z kim najczęściej plotkujemy w miejscu pracy udzielono następujących odpowiedzi:

- z osobą, której ufamy,

- z najbliższymi przyjaciółmi z pracy

- z kolegami,

- ze współpracownikami.

Na pytanie 3: na jakie tematy plotkujemy? 19\% badanych odpowiedziało: tematy związane pracą, np. jakość pracy innych osób, $6 \%$ badanych: dieta, $6 \%$ badanych: sport, $31 \%$ badanych: współpracownicy, $25 \%$ odpowiedziało: sprawy osobiste, $13 \%$ badanych odpowiedziało: relacje między ludźmi. Wyniki można przestawić za pomocą następującego wykresu:

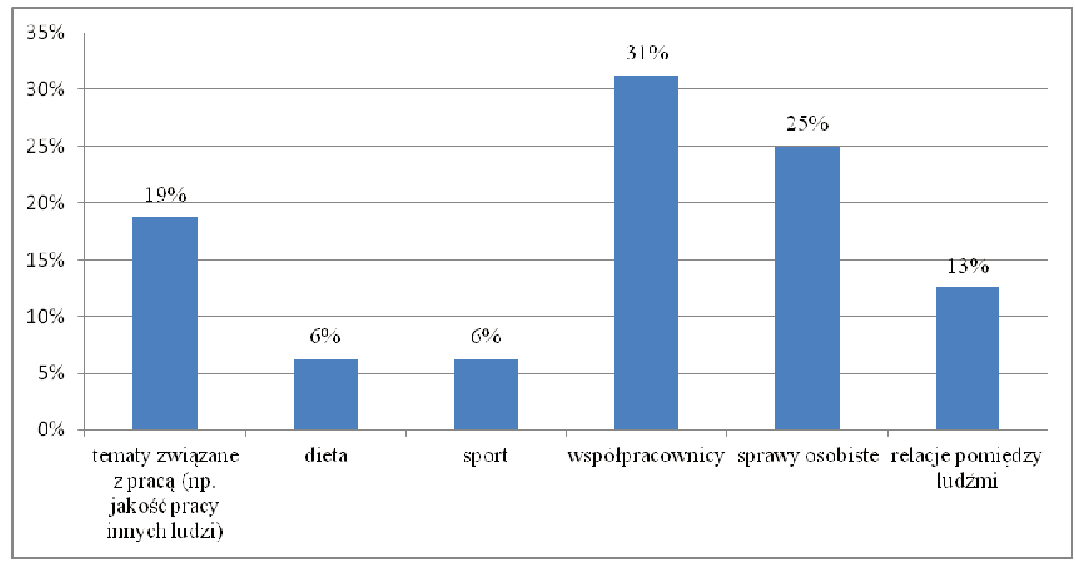

Wykres 2. Na jakie tematy plotkujemy? 
Na pytanie 4: o jakiej porze dnia najczęściej plotkujemy? 21\% badanych odpowiedziało: rano, po przyjściu do pracy. 58\% badanych odpowiedziało: w przerwie, podczas wykonywania pracy, $21 \%$ badanych odpowiedziało: po południu, przed zakończeniem pracy. Otrzymane wyniki można przedstawić za pomocą następującego wykresu:

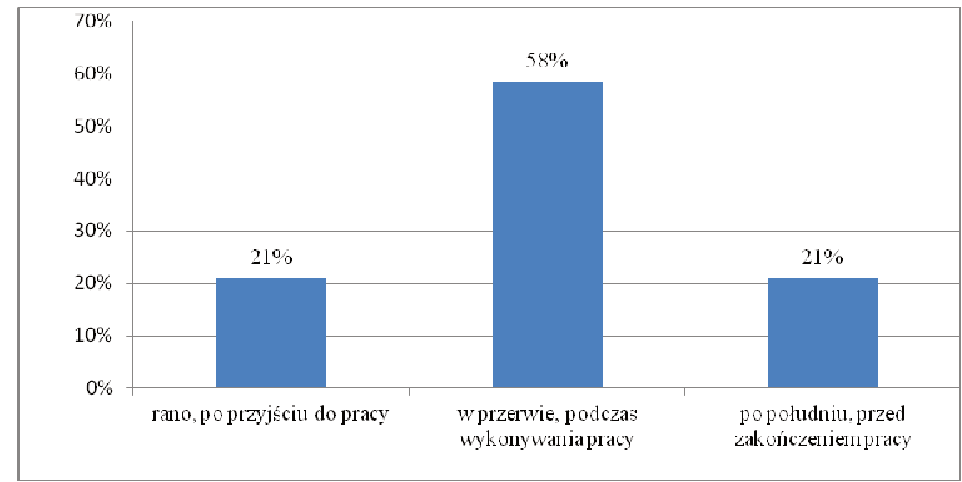

Wykres 3. O jakiej porze dnia najczęściej plotkujemy?

Na pytanie 5: w jakim miejscu najczęściej plotkujemy? 74\% odpowiedziało: miejsce pracy (np. biuro), 22\% badanych odpowiedziało: korytarz, $4 \%$ badanych odpowiedziało: toaleta. Wyniki można przedstawić za pomocą następującego wykresu:

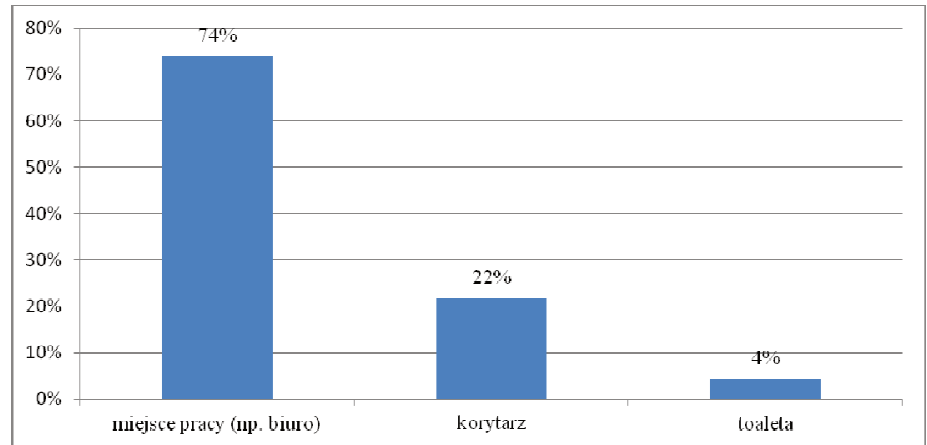

Wykres 4. W jakim miejscu najczęściej plotkujemy?

Na pytanie 6: jak często plotkujemy? 9\% badanych odpowiedziało: raz dziennie, $50 \%$ badanych odpowiedziało: kilka razy dziennie, $14 \%$ badanych odpowiedziało: raz w tygodniu, $27 \%$ badanych odpowiedziało: kilka razy w tygodniu. Wyniki można przedstawić za pomocą następującego wykresu: 


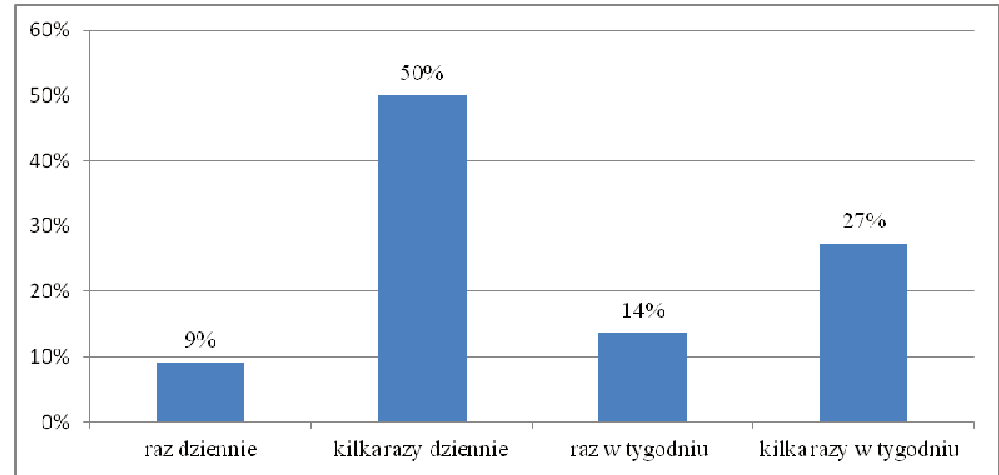

Wykres 5. Jak często plotkujemy?

Na pytanie 7: dlaczego plotkujemy $w$ miejscu pracy ? udzielono następujących odpowiedzi:

- plotkujemy żeby być częścią grupy,

- dla zabicia czasu,

- plotkujemy, żeby podtrzymać kontakt z innymi, wzmacniamy więzi społeczne,

- wymieniamy się informacjami,

- plotkujemy, żeby odreagować stres,

- plotkujemy z ciekawości, żeby podtrzymać rozmowę,

- plotkujemy, żeby poprawić sobie humor,

- lubimy porównywać się z innymi ludźmi.

Na pytanie 8: kto najczęściej plotkuje w miejscu pracy: młodsi stażem pracownicy czy starsi stażem pracownicy? 14\% badanych odpowiedziało: młodsi stażem pracownicy, 86\% odpowiedziało: starsi stażem pracownicy. Otrzymane wyniki można przedstawić za pomocą następującego wykresu:

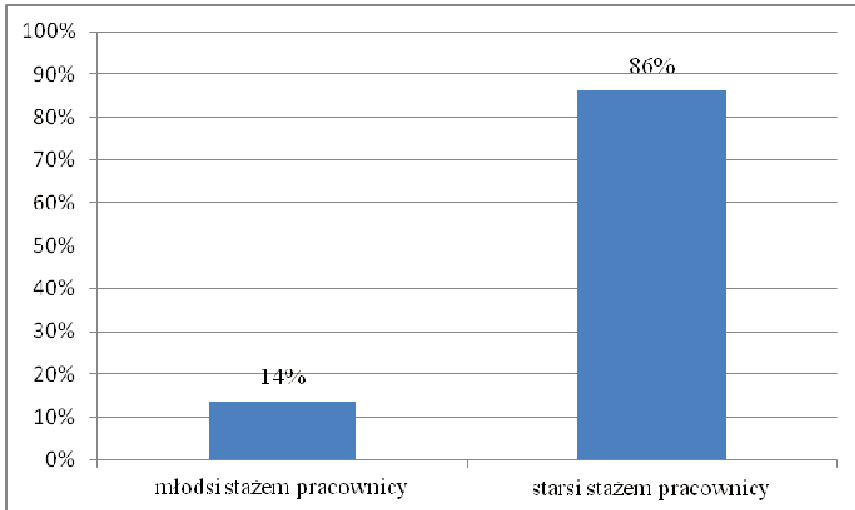

Wykres 6. Kto najczęściej plotkuje w miejscu pracy? 
Na pytanie 9: czy wierzysz $w$ plotki poruszane $w$ Twoim miejscu?. 44\% ankietowanych odpowiedziało: tak, 56\% badanych odpowiedziało: nie. Wyniki można przedstawić za pomocą następującego wykresu:

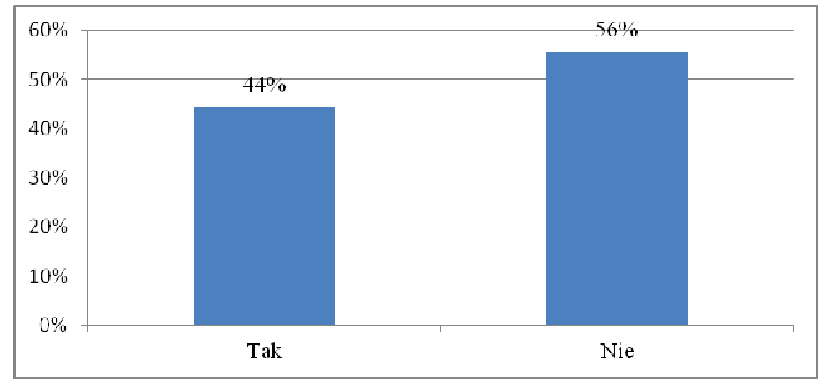

Wykres 7. Czy wierzysz w plotki poruszane w Twoim miejscu pracy?

Na pytanie 10: jakich zasobów używaja osoby, które plotkują w Twoim miejscu pracy? $88 \%$ badanych odpowiedziało: zasoby potoczne języka. 13\% odpowiedziało: wulgaryzmy.

Na pytanie 11: jakie zasoby językowe wykorzystywane są podczas plotkowania? 20\% ankietowanych odpowiedziało: wysokie, 60\% odpowiedziało: nisko-średnie, 20\% ankietowanych odpowiedziało: niskie. Wyniki można przedstawić za pomocą następującego wykresu:

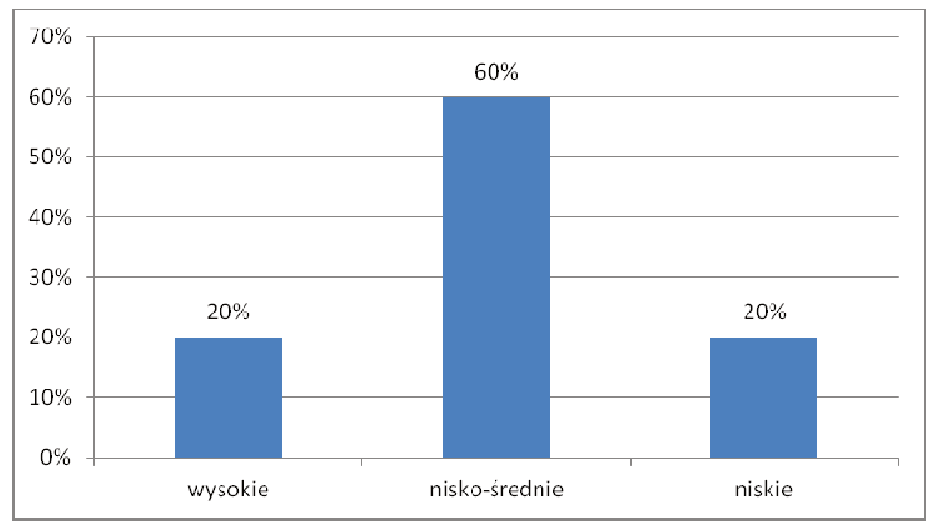

Wykres 8. Jakie zasoby językowe wykorzystywane są podczas plotkowania?

Na pytanie 12: czy podczas plotkowania dochodzi do skrócenia dystansu międzyosobowego? 90\% badanych odpowiedziało: Tak, 10\% odpowiedziało: Nie. Wyniki można przedstawić za pomocą następującego wykresu: 


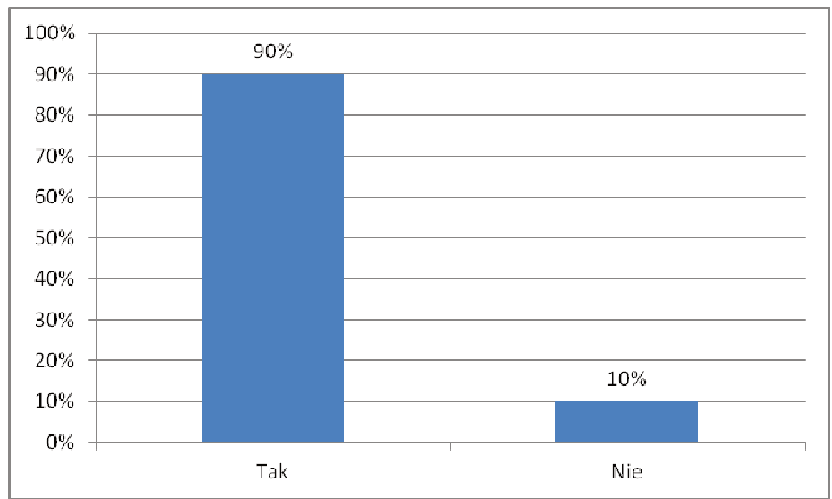

Wykres 9. Czy podczas plotkowania dochodzi do skrócenia dystansu międzyosobowego?

Na pytanie 13: jaki jest odstęp pomiędzy plotkujacymi w miejscu pracy? $10 \%$ badanych odpowiedziało: $45 \mathrm{~cm}, 60 \%$ odpowiedziało: od 45 do $120 \mathrm{~cm}, 20 \%$ odpowiedziało: od 120 do $360 \mathrm{~cm}, 10 \%$ odpowiedziało: powyżej $3,5 \mathrm{~m}$. Wyniki można przedstawić za pomocą wykresu:

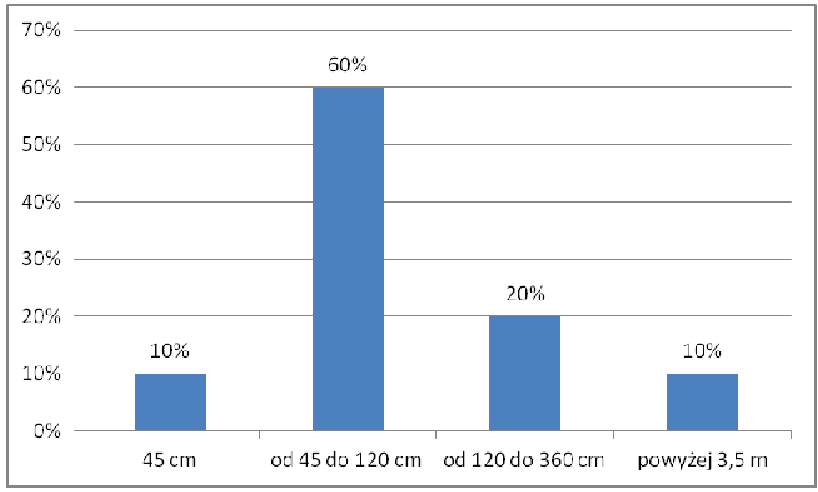

Wykres 10. Jaki jest odstęp pomiędzy plotkującymi w miejscu pracy?

W II części ankiety pilotażowej uczestniczyło 30 osób. Ankieta została przeprowadzona w kwietniu 2020 roku w okresie epidemii koronowirusa wśród osób aktywnych zawodowo. Ankieta składała się z 8 pytań. Została przeprowadzona, by zebrać opinie na temat plotkowania w Internecie, w szczególnej sytuacji pracy zdalnej, a co za tym idzie zmiany charakteru miejsca pracy i typu kontaktu. Celem ankiety było uzyskanie odpowiedzi na następujące pytania:

1) W jaki sposób wykonujesz swoją pracę w okresie pandemii koronowirusa?

2) Czy plotkujesz w godzinach pracy?

3) Jakie aplikacje można wykorzystać do plotkowania w godzinach pracy? 
4) Ile czasu spędzasz na plotkowaniu w godzinach pracy?

5) Na jakie tematy plotkujesz w godzinach pracy?

6) Czy plotkowanie skutkuje wyrobieniem sobie pozytywnego lub negatywnego wizerunku o przedmiocie lub człowieku, którego dotyczą plotki?

7) Czy plotkowanie w pracy prowadzi do zerwania relacji z człowiekiem, który jest obiektem plotek?

8) Czy plotkowanie prowadzi do domysłów na temat zachowania człowieka, którego dotyczą plotki?

Zebranie wyniki można przedstawić w następujący sposób:

Na pytanie 1: w jaki sposób wykonujesz swoja pracę $\mathrm{w}$ okresie pandemii koronawirusa? $70 \%$ badanych odpowiedziało: zdalnie, $20 \%$ respondentów odpowiedziało: pracuję w miejscu pracy, $10 \%$ ankietowanych odpowiedziało: nie pracuję. Wyniki można przedstawić za pomocą następującego wykresu:

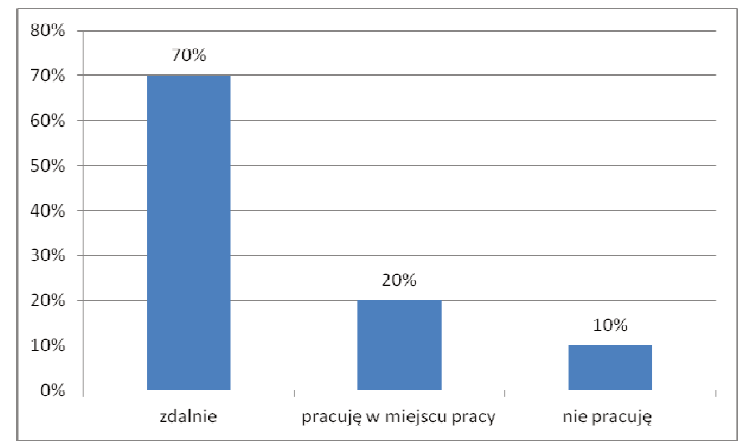

Wykres 11. W jaki sposób wykonujesz swoją pracę w okresie pandemii?

Na pytanie 2: czy plotkujesz $w$ godzinach pracy? 50\% badanych odpowiedziało: nie, 30\% badanych odpowiedziało: tak, $20 \%$ badanych odpowiedziało: rzadko. Otrzymane wyniki można przedstawić za pomocą następującego wykresu:

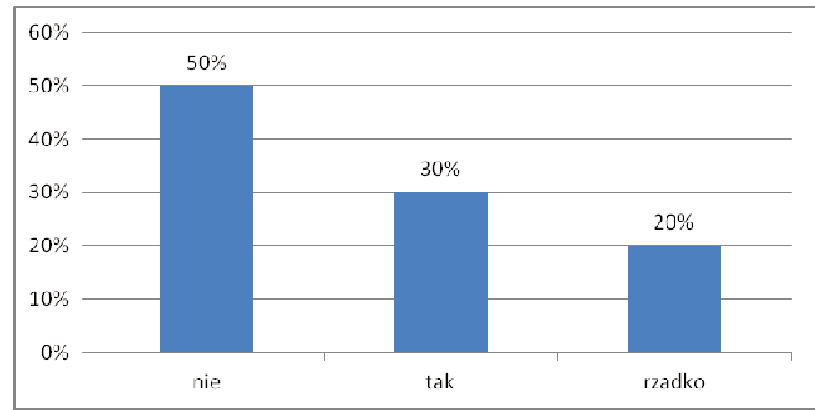

Wykres 12. Czy plotkujesz w godzinach pracy w okresie pandemii? 
Na pytanie 3: jakie aplikacje można wykorzystać do plotkowania $w$ godzinach pracy? 67\% respondentów podało: messenger, 33\% badanych odpowiedziało: whats up. Zebrane wyniki można przedstawić za pomocą następującego wykresu:

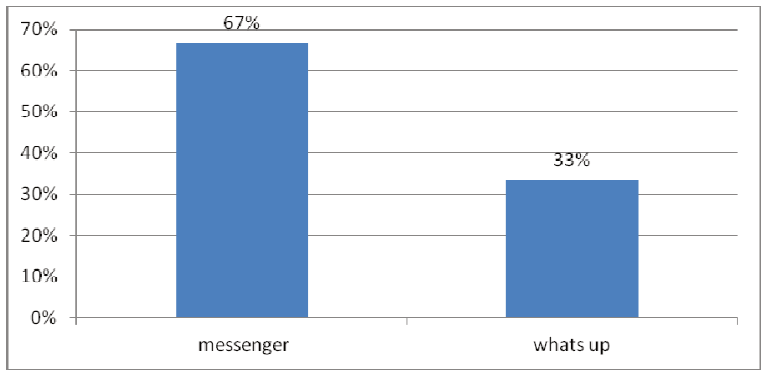

Wykres 13. Jakie aplikacje można wykorzystać do plotkowania w okresie pandemii koronowirusa?

Na pytanie 4: ile czasu dziennie spędzasz na plotkowaniu w czasie pracy udzielono następujących odpowiedzi: 50\% ankietowanych odpowiedziało: nie zajmuję się plotkami, $40 \%$ badanych podało: godzinę, 10\% respondentów odpowiedziało: pół godziny. Zebrane wyniki można przedstawić za pomocą następującego wykresu:

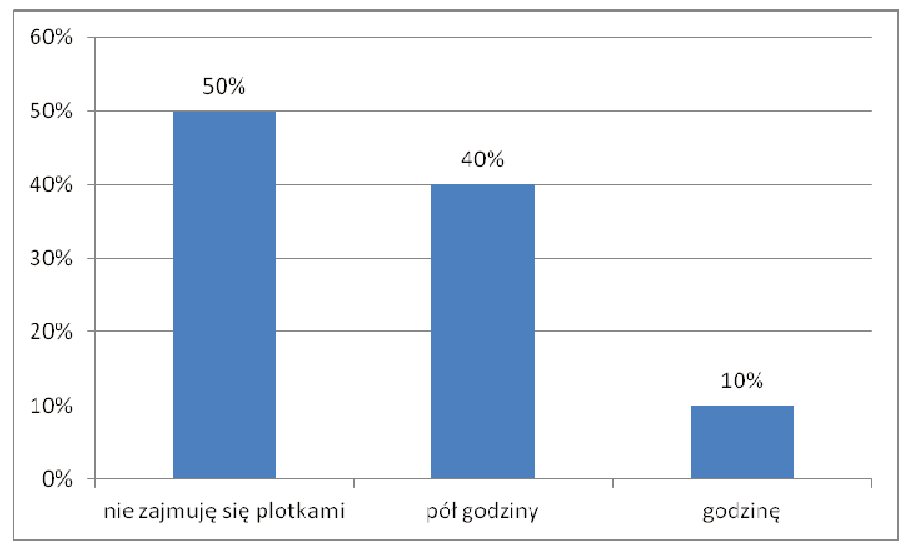

Wykres 14. Ile czasu dziennie spędzasz na plotkowaniu w godzinach pracy?

Na pytanie 5: na jakie tematy plotkujesz $w$ godzinach pracy udzielono następujących odpowiedzi:

- na temat kontaktów towarzyskich,

- na temat jak długo potrwa epidemia i czy będziemy mieli pracę,

- na tematy polityczne,

- na tematy zdrowotne. 
Na pytanie 6: czy plotkowanie skutkuje wyrobieniem sobie pozytywnego lub negatywnego wizerunku o przedmiocie lub człowieku, którego dotycza plotki 60\% badanych odpowiedziało: plotkowanie skutkuje wyrobieniem sobie negatywnego wizerunku, $40 \%$ badanych odpowiedziało: plotkowanie skutkuje wyrobieniem sobie negatywnego wizerunku. Zebrane wyniki można przedstawić za pomocą następującego wykresu:

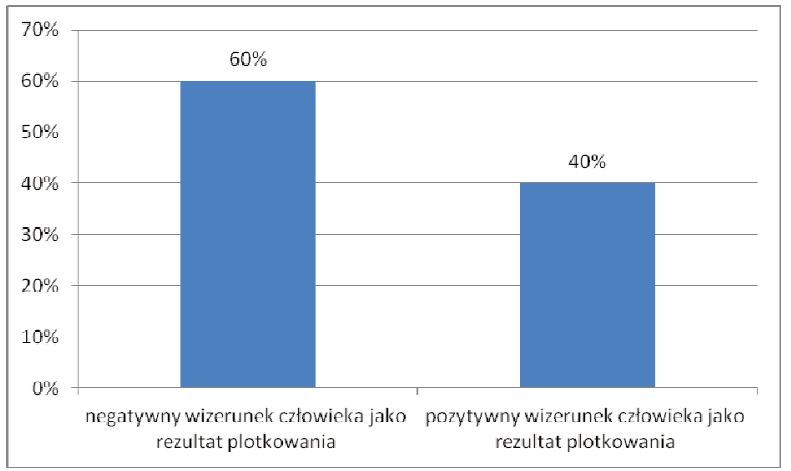

Wykres 15. Czy plotkowanie skutkuje wyrobieniem sobie pozytywnej lub negatywnej o przedmiocie lub człowieku, którego dotyczą plotki?

Na pytanie 7: czy plotkowanie prowadzi do zerwania relacji z czlowiekiem, który jest przedmiotem plotek $70 \%$ badanych odpowiedziało: tak, 30\% badanych odpowiedziało: nie. Zebrane wyniki można przedstawić za pomocą następującego wykresu:

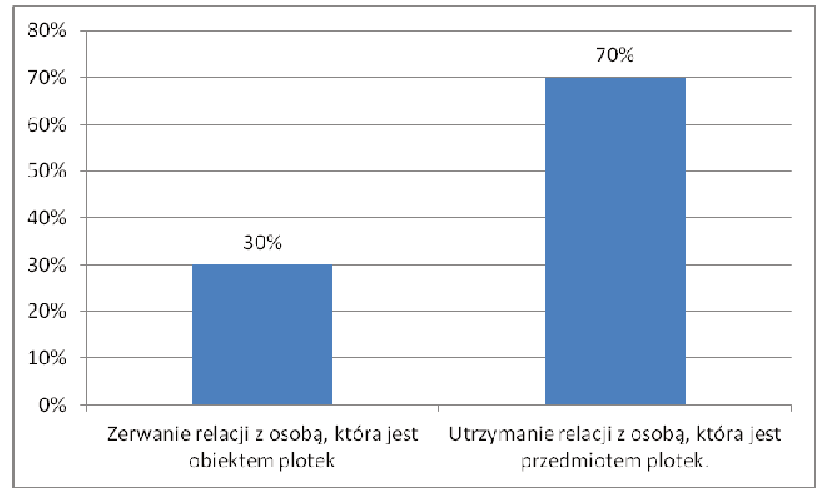

Wykres 16. Czy plotkowanie prowadzi do zerwania relacji z człowiekiem, który jest przedmiotem plotek?

Na pytanie 8: czy plotkowanie prowadzi do domystów na temat zachowania czlowieka, którego dotycza plotki 70\% badanych odpowiedziało: tak, 30\% badanych 
odpowiedziało: nie. Zebrane wyniki można przedstawić za pomocą następującego wykresu:

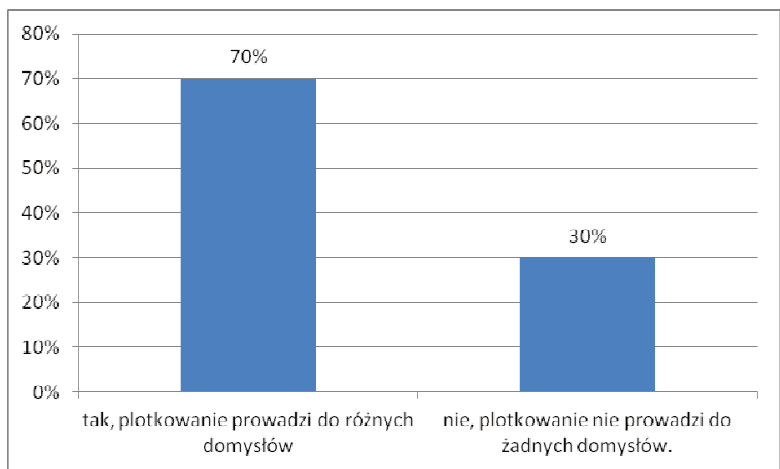

Wykres 17. Czy plotkowanie prowadzi do domysłów na temat zachowania człowieka, którego dotyczą plotki?

\section{Analiza}

Wyniki badania wskazują, że plotkowanie pełni funkcję integracyjną w formalnym układzie miejsca pracy, co stanowi potwierdzenie przyjętej na początku artykuły hipotezy badawczej. Plotka jest chętnie uprawiana w spotkaniach towarzyskich najczęściej w przerwie od pracy. Według osób badanych, plotkujemy w miejscu pracy, nie tylko żeby być częścią grupy (przynależność grupowa) ale również w celu podtrzymania kontaktu werbalnego z innymi, wzmocnienia więzi. Plotkujemy także, żeby poprawić sobie humor, w celu podtrzymania rozmowy $\mathrm{z}$ innymi osobami wchodzącymi w skład danej grupy w miejscu pracy oraz odreagowania na stres. Respondenci również wskazują, że plotkowanie odbywa się w określonej przestrzeni pracowniczej w miejscu pracy (pokoju, sali). Jest to zgodne z tym, co podaje Puppel (2004) odnośnie do odbywania aktów komunikacji w określonej przestrzeni społecznej oraz biologicznej. Podaje on, że jednym z ważnych czynników jest współzależność oraz interakcja pomiędzy rozmówcami. Jak już powiedziano, plotki powstają zazwyczaj w trakcie przerwy od pracy. Większość ankietowanych wskazuje, że do plotkowania wykorzystują zasoby nisko-średnie języka. Plotkowania prowadzi do skrócenia dystansu międzyosobowego. Odstęp fizyczny pomiędzy plotkującymi w komunikacji może wynosić od $45 \mathrm{~cm}$ do $120 \mathrm{~cm}$.

Natomiast inaczej wygląda komunikacja w okresie izolacji społecznej spowodowanej pandemią. Jest to głównie komunikacja elektroniczna, w której najpopularniejszymi aplikacjami używanymi do plotkowania są: messenger oraz whats up. Niemniej jednak połowa badanych stwierdziła, że nie uprawia plotek w czasie pracy zdalnej. Można również zauważyć różnice w sposobie plotkowania podczas bezpo- 
średniego spotkania w miejscu pracy oraz izolacji społecznej. Plotkujemy zazwyczaj z osobami, którym ufamy, bardzo często kilka razy dziennie w miejscu pracy w sytuacji kontaktu międzyosobowego. W sytuacji izolacji społecznej plotkowanie schodzi na plan dalszy. Wyniki badania wskazują, że plotkowanie nie odgrywa bardzo ważnej roli w tym okresie. Według ankietowanych do plotkowania używamy zasobów języka potocznego. Przykładowo, cytowane powyżej Boksa i Kołodziejczak (2019: 300), w językowej strukturze plotki wydzielają następujące parametry: „,pytanie”, „,nastawienie na sensacje”, ,jako zabezpieczenie”, „konstrukcja bezosobowa" Przykłady wyżej wspomnianych parametrów można przedstawić w następujący sposób:

Tabela 1. Konstrukcja plotki z punktu widzenia języka (Boksa i Kołodziejczak, 2019: 32).

\begin{tabular}{|c|c|c|c|}
\hline Pytanie & $\begin{array}{l}\text { Nastawienie } \\
\text { na sensacje }\end{array}$ & Jako zabezpieczenie & $\begin{array}{l}\text { Konstrukcja } \\
\text { bezosobowa }\end{array}$ \\
\hline \begin{tabular}{|l|} 
Ej, słyszałeś... \\
A wiecie, że... \\
Wiesz, czego ostatnio się \\
dowiedziałem... \\
Idziemy na kawcie poplot- \\
kować? \\
Chcesz usłyszeć porcję, \\
świeżych ploteczek? \\
A słyszałaś, że... \\
Wiedziałeś o tym? \\
Wiesz, co zrobiła? \\
Wiesz co? \\
Powiedzieć ci coś?
\end{tabular} & $\begin{array}{l}\text { Mam newsa? } \\
\text { Podobno... } \\
\text { Nie uwierzysz! } \\
\text { Mówiłam ci, że... } \\
\text { Muszę ci coś powiedzieć! } \\
\text { Zaraz ci coś powiem! } \\
\text { A przy okazji powiem ci... }\end{array}$ & $\begin{array}{l}\text { Nie to, że plotkuję, } \\
\text { Żeby nie było, to wiem od } \\
\text { Bartka... } \\
\text { Przeczytałam w Internecie... } \\
\text { Ostatnio koleżanka wspo- } \\
\text { mniała, ale nie wiem czy to } \\
\text { prawda } \\
\text { Opowiem ci coś, ale obiecaj, } \\
\text { że nikomu nie powiesz... } \\
\text { Głównie nie interesuje mnie } \\
\text { to, ale nie daje spokoju... } \\
\text { Tylko nie mów nikomu, bo } \\
\text { tylko tobie mówię... }\end{array}$ & $\begin{array}{l}\text { Powiedziano mi... } \\
\text { Sugerowano... } \\
\text { Pojawiła się sugestia, że... } \\
\text { Ujawniono dane... } \\
\text { Wiadomo, żę... } \\
\text { Trzeba się przyjrzeć }\end{array}$ \\
\hline
\end{tabular}

Osoby badane również podkreślają, że plotkowanie jest formą komunikacji, do tworzenia której używamy niskich zasobów języka potocznego. Takie stanowisko zajmuje Jacek Warchala (2003: 27), który twierdzi, że:

„gdy mówimy o najprostszych codziennych sprawach, używamy codziennego języka, który jest dla nas naturalnym (...) sposobem komunikowania, naszą bazą, swoistym punktem odniesienia. Tu znajdziemy podstawowy repertuar form i znaczeń potrzebnych w sytuacjach codziennych kontaktów międzyludzkich. A one umożliwiają nam wyrażenie podstawowych potrzeb egzystencjalnych, a także pozwalają sprowadzić wyrażenia i zwroty skomplikowane czy wyspecjalizowane do prostych, łatwo pojmowalnych".

Warto podkreślić w tym miejscu, że jedynie 13\% badanych podało, że wulgaryzmy są używane podczas plotkowania. Zatem osoby plotkujące można opisać odnosząc się do syndromu Guliwera, a więc jako te, które ,zmieniają natężenie zasobów językowych każdorazowego dla konkretnego aktu komunikacyjnego w zderzeniach komunikacyjnych z innymi agensami” (Puppel, 2004 w Krawczak, 2017: 154). Wy- 
niki badania również wskazują, na tematy plotek. Według badanych najczęściej plotkujemy na temat współpracowników. W trakcie pandemii tematami plotek najczęściej są długość jej trwania oraz czy dalej będziemy posiadać swoją pracę jak również tematy towarzyskie, polityczne oraz zdrowotne. Ponadto $z$ badania wynika, że plotkowanie prowadzi najczęściej do wytworzenia negatywnego wizerunku osoby, która jest przedmiotem plotek. Badane osoby podają, że plotkowanie nie prowadzi jednak do zerwania kontaktu z osobą, która jest obiektem plotek. Respondenci podają również, że plotkowanie prowadzi do domysłów na temat osób, które są obiektem plotek. Według ankietowanych najczęściej plotkują osoby starsze stażem. Powstaje w tym miejscu pytanie dlaczego częściej plotkują osoby starsze stażem? Przyjmujemy, że osoby starsze i z dłuższym stażem mają poczucie większego zaufania do swoich współpracowników, dlatego są bardziej skłonne do plotkowania niż osoby o krótszym stażu. Zagadnienie to wymaga jednak dodatkowych badań.

\section{Wnioski końcowe}

Plotkowanie jako część interakcji międzyludzkich o charakterze werbalnym odbywa się w różnych obszarach życia ludzkiego: środowisku domowym, koleżeńskim, zawodowym. Na podstawie tak szerokiego spektrum uprawiania plotki można stwierdzić, że plotkowanie jest niezwykle ważnym elementem życia społecznego, w tym zawodowego, że jest jedną z form komunikacji o charakterze werbalnym $\mathrm{w}$ formalnym układzie miejsca pracy a także pełni niezwykle istotną funkcję integracyjną. W niniejszym artykule zjawisko plotki i proces plotkowania zostały pokrótce przedstawione z różnych perspektyw: socjolingwistycznej, pragmalingwistycznej, psycholingwistycznej oraz ekolingwistycznej. W perspektywie socjolingwistycznej proces plotkowania ujęto jako spotkania $\mathrm{z}$ rozmówcą na osobności $\mathrm{W}$ perspektywie pragmalingwistycznej plotkę ujęto jako zjawisko, które odnosi się do mechanizmu przekazywaniu informacji o charakterze użytecznym dla komunikatorów za pomocą głównie zasobów potocznych języka. Podkreślono, że najczęściej plotkujemy z osobą, której ufamy, z najbliższymi przyjaciółmi z pracy, z kolegami, ze współpracownikami. Jak już podkreślono, plotkujemy za pomocą zasobów potocznych języka.

Bardzo ważnymi elementami plotki i plotkowania są psychologiczne oraz ekolingwistyczne aspekty plotki. Jak wskazano w tekście artykułu, plotka wykorzystywana jest przez komunikatorów do stosowania i utrzymywania zasobów niskośrednich języka. Podkreślono także, że plotkowanie prowadzone jest w warunkach skróconego dystansu międzyosobowego w komunikacji międzyosobowej (zob. np. J. Puppel, 2007) głównie w celu podtrzymania kontaktu z rozmówcą/interlokutorem. Pokrótce plotka omówiona została z punktu widzenia psychologii, a więc z punktu widzenia pewnych tendencji w jej używaniu na podłożu różnic związanych ze społeczno-kulturowym funkcjonowaniem płci (genderowość). 
Z odpowiedzi osób ankietowanych wynika, że plotkowanie jest ważną częścią życia zawodowego. Plotkujemy z różnych powodów, np. żeby być częścią grupy, dla zabicia czasu. Plotkowanie wzmacnia więzi społeczne, komunikatorzy w sposób naturalny wymieniają się informacjami, plotkują, żeby odreagować napięcia, z ciekawości, żeby uzyskać nową informację, żeby podtrzymać rozmowę, żeby poprawić sobie humor, żeby porównywać się z innymi ludźmi w ramach mechanizmu kompensacyjnego, zgodnie z którym plotka ma dać uprawiającym ją jakieś poczucie wyższości lub przynajmniej poczucie bycia równym z innymi.

Artykuł wskazuje na istotne różnice w procesie plotkowania w trakcie kontaktu osobistego oraz izolacji społecznej spowodowanej pandemią koronowirusa. W czasie pandemii plotkowanie odbywa się przede wszystkim za pomocą takich aplikacji elektronicznych jak messenger, whats up. Najczęściej podczas pandemii poruszane są tematy plotkowania dotyczące kontaktów towarzyskich, polityki, zdrowia, długości trwania pandemii i przyszłości, np. czy będziemy mieli pracę. Przeprowadzone badanie pilotażowe pokazuje, że warto badać plotkę w interakcjach zawodowych wieloaspektowo.

Przedstawione w niniejszym artykule zagadnienia mają charakter wstępny i mogą stanowić punkt wyjścia do dalszych badań nad plotką w różnych układach interakcyjno-komunikacyjnych (np. zawodowym). Na szczególną uwagę zasługuje charakter ekolingwistyczny uprawiania plotki, gdyż rzuca on światło na obecność plotki i plotkowania jako ważnego mechanizmu utrzymywania nisko-średnich zasobów językowych danej wspólnoty kulturowo-językowej. Zasoby te, należy to podkreślić, stanowią jądro każdego języka naturalnego i jako takie mają podstawowe znaczenie dla jego utrzymania w globalnej arenie języków naturalnych.

\section{Bibliografia}

Berg, J., J. Dickhaut i K. McCabe. 1995. "Trust, reciprocity, and social history”. Games and Economic Behavior 10.1. 122-142.

Bielak, M. 2019. „Etyka w tożsamości tłumacza kształtowanej w przestrzeni instytucjonalnej”. W zbiorze: Bielak, M., Krawczak, M. i W. Maliszewski (red.). Wymiary instytucjonalnej przestrzeni komunikacyjnej. Toruń: Wydawnictwo Adam Marszałek. 17-27.

Bilińska, M. 2009. „Plotka jako gatunek mowy i tekstu” W zbiorze: Kusal, K. (red.). Językoznawstwo: wspótczesne badania: problemy i analizy językoznawcze 3. Łódź: Akademia HumanistycznoEkonomiczna w Łodzi. Katedra Komunikacji Językowej AHE. 93-102.

Boksa, E. i J. Kołodziejczak. 2019. „Plotka z perspektywy interakcji językowej.” W zbiorze: Trzaskowski, Z. (red.). Studia filologiczne Uniwersytetu Jana Kochanowskiego. Kielce: Wydawnictwo Uniwersytetu Jana Kochanowskiego. 292-305.

Błachowicz-Wolny, E. 1995. „Plotka albo poczta pantoflowa jako ulubiona forma komunikacji międzyludzkiej”. W zbiorze: Satkiewicz, H. (red.). Poradnik językowy 2. Warszawa: Wydawnictwo Uniwersytetu Warszawskiego. 36-42.

Bronagh, A. i G.J. McKeown. 2020. „Creativity and gossip: investigating shared cognitive pathways and aesthetic appreciation”. Belfast: Queen's University Belfast (Poster). 
Dunbar, R. 1996. Grooming, gossip, and the evolution of language. Cambridge, Mass.: Harvard University Press. (Tłumaczenie polskie: Tomasz Pańkowski 2009. Pchly, plotki a ewolucja języka. Warszawa: Wydawnictwo Czarna Owca).

Eckhaus, E. i B. Ben-Hador. 2017. "Gossip and gender differences: a content analysis approach". Journal of Gender Studies 28.1.

Feinberg, M., R. Willer, J. Stellar i D. Keltner. 2012. "The virtues of gossip: reputational information sharing as prosocial behavior". Personality and Social Psychology 102.5. 1015-1030.

Foster, E.K. 2004. „Research on gossip: taxonomy, methods, and future directions”. Review of General Psychology 8. 78-99.

Gronowski, D. 2016. „Plotkowanie jako fenomen komunikacyjny.” W zbiorze: Leśniczak, R. (red.). Łódzkie Studia Teologiczne. Tom 25. Łódź: Archidiecezjalne Wydawnictwo Łódzkie. 59-71.

Gruchoła, M. i E. Kruczek. 2013. „Elementy wizerunku medialnego w internetowych serwisach plotkarskich w świetle badań ankietowych”. W zbiorze: Nowak, M. (red.). Rozprawy społeczne 1. Tom 7. Biała Podlaska: Państwowa Szkoła Wyższa im. Papieża Jana Pawła II w Białej Podlaskiej. $137-146$.

Hansen, A. 2020. Wyloguj swój mózg. Kraków: Wydawnictwo Znak.

Jęczeń, A. 2011. „Komunikacja na granicy prawdy, czyli o plotce w kulturze masowej.” W zbiorze: Tatar, B. (red.). Acta Humana 2. Lublin: Uniwersytet Marii Curie-Skłodowskiej. 109-121.

Jourard, S.M. 1959. "Self-disclosure and other-cathexis". Journal of Abnormal and Social Psychology 59.3. 428-431.

Jung, C.G. 1921/1971. Psychological types. Collected works. Vol. 6. Princeton, N.J.: Princeton University Press.

Krawczak, M. 2017. „Poznańska szkoła ekolingwistyki” W zbiorze: Puppel, S (red.). Scripta Neophilologica Posnaniensia. Tom VII. Poznan. Wydział Neofilologii UAM. 145-193.

Kurządkowska, B. i M. Maruszczak. 2014. „Mem - współczesna plotka internetowa”. W zbiorze: Burska, K., Cieśla, B (red). Kreatywność językowa w przestrzeni medialnej. Łódź: Wydawnictwo Uniwersytetu Łódzkiego.

Leaper, C. i H. Holliday. 1995. "Gossip in same-gender and cross-gender friends' conversations". Personal Relationships 2.3. 237-246.

Leaper, C. i C.K. Friedman. 2007. "The socialization of gender". W zbiorze: Grusec, J.E, i P.D. Hastings. (red.). Handbook of socialization: theory and research. New York: The Guilford Press. 561-587.

Levin, J. i A. Arluke. 1985. "An exploratory analysis of sex differences in gossip". Sex Roles 12. 281-286.

Mateja, M. 2010. „Płeć (niezbyt piękna): kobiety jako bohaterki i użytkowniczki internetowych serwisów plotkarskich". W zbiorze: Mateja, M., Wincławska, M. i B. Brodzińska (red.). Konteksty kultury popularnej: pteć, sztuka, media. Toruń: Wydawnictwo Adam Marszałek.

Nettle, D. 2007. „Individual differences”. W zbiorze: Dunbar, R.I.M. i L. Barrett. (red.). Oxford handbook of evolutionary psychology. Oxford: Oxford University Press.

Puppel, J. 2007. „Wpływ dystansu międzyosobowego na użycie zasobów językowych w komunikacji bezpośredniej: badania wstępne”. W zbiorze; Puppel, S. (red.). Społeczeństwo - kultura - język. $W$ strone interakcyjnej architektury komunikacji. Scripta de Communicatione Posnaniensi. Seria: Prace Naukowe Katedry Ekokomuniacji UAM. Tom I. Poznań: Zakład Graficzny UAM. 65-77.

Puppel, S. i J. Puppel. 2008. „Gestosfera jako istotny składnik przestrzeni publicznej: wstępny zarys problematyki. Electronic Journal Oikeios Logos 4. Poznań: Katedra Ekokomunikacji UAM. 1-8.

Puppel, S. 2004. „An outline of a domain-resource-agent-access-management (DRAAM) model of human communication: towards an ecology of human communication". Electronic Journal Oikeios Logos 1. Poznań: Katedra Ekokomunikacji UAM. 1-26. 
Puppel, S. 2011. "An outline of a multiply triune continuum model of language and communication". Electronic Journal Oikeios Logos 8. Poznań: Katedra Ekokomunikacji UAM. 1-25.

Puppel, S. 2013. „A Communications manifesto (evolving)”. W zbiorze: Puppel, S (red.). Scripta Neophilologica Posnaniensia. Tom XIII. 91-101.

Puppel, S. 2015. „Język w podmuchu, posiewie i przepływie: uwagi w sprawie synergii porządków komunikacyjnych w kontekście ekoglottodydaktyki” W zbiorze: Puppel, S (red.). Motek. Motywy ekolingwistyczne: w stronę ekoglottodydaktyki. Scripta de Communicatione Posnaniensi Seria: Prace Naukowe Katedry Ekokomunikacji UAM. Tom VII. Poznań: Zakład Graficzny UAM. $143-150$.

Puppel, S. 2016. „Uwagi w sprawie kołowo-piramidalnego modelu przepływu energii w otwartym układzie "cielesność ludzka - kultura - język". W zbiorze: Waligórska-Olejniczak, B., Królikiewicz, N. i K. Kropaczewski (red.). Zjawisko energii w nauce, sztuce i kulturze. Prace Humanistycznego Centrum Badań „DYSKURS WIELOKULTUROWY”. Poznań: Zakład Graficzny UAM. 43-52.

Puppel, S. 2017. ECOLIS': essays and notes on ecolinguistic synergy and synthesis. Scripta de Communicatione Posnaniensi. Seria: Prace Naukowe Katedry Ekokomunikacji UAM. Tom. VIII. Poznań: Zakład Graficzny UAM.

Reykowski, J. 1974. Eksperymentalna psychologia emocji. Warszawa: Książka i Wiedza.

Szczerba, G. 2013. Menadżer doskonaty: komunikacja. Gliwice: Złote Myśli.

Thiele-Dohrmann, K. 1975. Unter dem Siegel der Verschwiegenheit: die Psychologie des Klatsches. Verlag: Claassen, Düsseldorf (Tłumaczenie polskie: Andrzej Krzemiński 1980. Psychologia plotki. Warszawa: Państwowy Instytut Wydawniczy).

Wagner, A. 2006. „Plotka jako narzędzie kształtowania rzeczywistości społecznej. Afera Rywina w dyskursie prasowym". W zbiorze: Wasilewski, J. (red.). Studia Socjologiczne $n r$ 4. Warszawa: Polska Akademia Nauk. Komitet Socjologii. Instytut Filozofii i Socjologii. 40-67.

Warchala, J.2003. Kategoria potoczności w języku. Katowice: Wydawnictwo Uniwersytetu Śląskiego.

Watson, D.C. 2012. „Gender differences in gossip and friendship”. Sex Roles. A Journal of Research $66.1 / 2$

Wąsik, E. 2007. Język: narzędzie czy właściwość człowieka. Założenia gramatyki ekolingwistycznej zwiqzków międzyludzkich. Poznań. Wydawnictwo Naukowe UAM.

Wiertlewska, J. 2014. Ekolingwistyczne podejście do nauczania języków obcych na przykładzie języka angielskiego - wyzwaniem dla glottodydaktyki XXI wieku. Bydgoszcz: Collegium Medicum im. Ludwika Rydygiera.

Wilson, F.M. 2010. Organizational behaviour and work: a critical introduction. Oxford/New York: Oxford University Press.

\section{Źródla Internetowe}

ŹI - Źródło Internetowe

ŹI 1 - https://gloria.tv/post/HiodtGksMJgM3ii9uUawLZ2Hc data dostępu - 01.02.2020 r.

ŹI 2 - http://publictionnaire.huma-num.fr/notice/bouche-a-oreille/ data dostępu - 03.03.2020 r.

ŹI 3 - https://natemat.pl/54907,my-rozmawiamy-i-wymieniamy-sie-doswiadczeniami-czyli-o-czym-i-jakplotkuja-faceci data dostępu-06.04.2020 r.

ŹI 4 - https://people.howstuffworks.com/gossip1.htm data dostępu - 06.04.2020 r.

ŹI 5 - https://www.glospedagogiczny.pl/artykul/rozwoj-mowy-a-zaburzenia-integracji-sensorycznej data dostępu - 06.04.2020 r.

ŹI 6 - https://people.howstuffworks.com/gossip.htm data dostępu - 06.04.2020 r. 